\title{
The Problem of Determining the Law Applicable to Damageable Act in the High Seas Pursuant to the Jordanian International Private Law
}

\author{
Khaldoun Said Saleh Qtaishat ${ }^{1}$ \\ ${ }^{1}$ Faculty of Law, University of Jordan, Jordan \\ Correspondence: Khaldoun Said Saleh Qtaishat, Faculty of Law, University of Jordan, Jordan. E-mail: \\ K.qtaishat@ju.edu.jo
}

Received: January 2, 2019

Accepted: January 18, 2019 Online Published: February 2, 2019

doi:10.5539/jpl.v12n1p11

URL: https://doi.org/10.5539/jpl.v12n1p11

\begin{abstract}
In the present article, the author examines one of the most important issues related to the international private law. This issue is how to determine the law applicable to damageable act in the high seas according to the Jordanian international private law. This problem is represented in the way of how the Jordanian legislator, in general, deals with the law applicable to the damageable act in the Jordanian civil code without dealing with the problem of identifying the law applicable to the damageable act in the high seas, which leads the author to ask and answer about how to determine the law applicable to this damageable act.

The jurisprudence of the international private law pays great deal of attention to the problem of the law applicable to damageable act on the high seas, where many opinions try to solve it. The international community also takes notice of this problem as well as the result of this attention the emergence of the Brussels maritime Collision Convention in 1910. It is worth mentioning that Jordanian legislator has addressed the issue of maritime collision in the Jordanian maritime commercial law which contains numerous provisions that match perfectly with the provisions of the Brussels Collision Convention in 1910.
\end{abstract}

Keywords: conflict of law, maritime collision, high seas

\section{Introduction}

Legislations all over the world, including the legislation of the Hashemite Kingdom of Jordan (the Jordanian Civil Code No. 43 of 1976) $)^{1}$, has interested in the finance civil rights as the personal right which is known as "the legal bond between a creditor and a debtor whereby the creditor demands the debtor to move a real right, or do or refrain to do a work"

These legislations have been organized the sources of the personal rights which include damageable act that is defined as "each physical work done by the person and happens on the money such as damaging, constraint and burning or happens on the self as killing, wounding, beating and harming and causes damage to someone else."

Article 256 of the Jordanian civil code states that "every damage to others obligates its doer even he/she is undiscerning to guaranty the damage." Thus, the pillars of damage are damageable act, damage and a causal relationship between them, so that rising non-contractual civil responsibility does not require occurrence of damage from the doer of the action, but actualized damage is only required.

One of the most important issues that arouse problems in the context of international private relations is determining the law applicable to damageable act. Article 22/1 of the Jordanian civil code provides that "the law of the country where the act that establishes obligation is applied on non-contractual obligations". It is obvious from this article that the Jordanian legislator, within the framework of international relations, requires applying the law of the place where the damageable act is occurred to determine the responsibility of the doer and responsibility extent. And thus the Jordanian legislator corresponds to with what prevailed among the scholars of

\footnotetext{
${ }^{1}$ Official Gazette, 1/8/1976, Issue 2645, p. 2

${ }^{2}$ Article 68 of Jordanian civil code No. 43 of 1976

${ }^{3}$ Daoudi, Ghalib Ali, "International Private Law, the First Book in the Conflict of Laws and Conflict of International Jurisdiction and Enforcement of Foreign Awards", Dar Wael for Publication, Amman, 2001, p 138.
} 
the theory of status since $13^{\text {th }}$ century, who were required applying this law ${ }^{4}$.

In spite of the logical application of the law place where the act is occurred and its agreement with the normal association between the damageable act and its place of occurrence, but another rule is found next to previous one in the middle of $19^{\text {th }}$ century. This rule went to the need to subject damageable act to the law of the judge's country on the grounds that the rules governing this act are imperative rules bind the judge by its provisions including those contained in his law despite those contained in the law of place where the act is occurred ${ }^{5}$.

However, some of the modern jurisprudence criticized the idea of domestic law according to its traditional concept. This part of jurisprudence stresses the need to find the prevailing law at the social center where the act establishing obligation is occurred. This part of jurisprudence believes that it is not right to understand the meaning of domestic law as the law of the place where the act establishing obligation is occurred, but rather on the grounds that it is the law governing the social environment or social center that legal incident occur in which resulted in the non-contractual obligation ${ }^{6}$.

Whatever the case is, the most important problems which are concerned with determining the law applicable to damageable act when it occurs in the high seas which is the topic of our present article. In this article, the researcher will discuss the solutions of the conflict of laws regarding a delicate issue of maritime law.

determining the law applicable to the damageable act that is located in a state based on the Jordanian rule of conflict adopted by the Jordanian legislator in article 22 can be easy, but to determine the law applicable to damageable act on the high seas, it is not an easy task as the Jordanian rule of conflict has to apply the law of the country in which the act originates the obligation has been occurred.

The importance of our present research lies in the absence of a rule of conflict in the Jordanian civil code in which the legislator can addresses the issue of damageable act that is located on the high seas. Therefore, how can the Jordanian judge determine the law applicable to this matter?

\section{The Concept of Damageable Act on the High Seas}

As understood from articles (58) and (86) of the UN Convention of 1986 known as Caracas Convention, high seas mean the parts of the sea that are not included in the concept of the territorial waters of coastal states or internal waters of states.

Thus, the term 'high seas' includes water that does not refer to a country or group of countries, i.e., the water is international waters. The high seas is considered international joint ownership so that all countries have right in the international waters, the freedom of navigation, freedom of fishing, freedom to lay marine pipelines and the freedom to fly in the air above them.

With regard to the concept of damageable act on the high seas, it is intended to mean maritime collision which means collision of vessels that breeds a special legal system to govern the damage resulting from it?

Jurisprudence has differed on the identification of the elements of the concept of maritime collision. Some of Jurisprudence focuses on the status of constructions or vessels that were party of the collision. A collision is considered a collision when two or more vessels collide with a vessel from inland navigation even though the collision occurred in inland waters ${ }^{8}$. Some other focuses on the water where the collision is happened regardless of the status of the vessels. A collision is considered a collision when it is on the high seas ${ }^{9}$, which the author tends to adopt it as a concept for the maritime collision so if the collision is in the territorial waters or in a river, it will not consider a maritime collision.

on the basis of the previous discussion, the collision or clash between two vessels from inland navigation located in the rivers and inland waters goes beyond the scope of the concept of the maritime collision, it also goes beyond the scope of the concept of the maritime collision which is happened between a vessel and the quay or

\footnotetext{
${ }^{4}$ Abdullah, Izz al-Din, "International Private Law, Part Two, in the International Conflict of Laws and International Conflict of Jurisdiction," Dar Al Nahda Al Arabia, Cairo, 1969, p. 496.

${ }^{5}$ ibid, pp.496-497

${ }^{6}$ Sadeq, Hisham Ali, "Lessons in Private International Law," Beirut Arab University, University Al Dar Al Jamiea for Printing and Publishing, pp. 270 and 276.

${ }^{7}$ Sadeq, Hisham Ali, "Conflict of Laws in Delictual Responsibility (Law of Torts) Issues Arising from Maitime Collision and Incidents Occurring on Vessels," Dar al Fikir Al Jamie, Alexandria, 2002, p. 66.

${ }^{8}$ ibid, p. 67

${ }^{9}$ ibid
} 
constructions attached to it $^{10}$.

Furthermore, collision that is occurred between vessels or river- boats with debris of other vessel or rocks on the high seas is excluded from the concept of maritime collision previously mentioned ${ }^{11}$.

It is worth mentioning in the context of the concept of the maritime collision, that Brussels Collision Convention of 1910 for the unification of certain rules related to maritime collisions provides that the maritime collision cannot be considered a collision only unless it occurred between two or more vessels, or at least between one vessel and any other boats of inland navigation regardless of the fact that this collision has occurred on the high seas or in the internal waters.

\section{The International Community Efforts to Unify the Rules of Liability for the Damageable Act on the High Seas}

Since the beginning, international community interested in the issue of maritime collision where resulted in from this interest of the draft convention adopted by the International Committee of the Maritime Law in 1896, which was the fruit of the conclusion of the Brussels Collision Convention on September 23, 1910 for the Unification of Certain Rules related to maritime collision ${ }^{12}$, which entered into force on 1 March 1913 (International Convention for the Unification of Certain Rules of Law Related to Collision between Vessels "Brussels Collision Convention 1910") and approved by Egypt in law No. 22 of 1941 and decreed-law on January 31, 1944 ${ }^{13}$, in which Jordan did not approve it up to this date ${ }^{14}$.

Accordingly, in the event of a maritime collision on the high seas between vessels belonging to countries approved the Brussels Collision Convention, the problem of conflict of laws in terms of place does not arise at all because provisions of this Convention must be applied.

When considering the provisions of this convention, which is the direct source of the substantive provisions in the framework of international relations related to maritime collision ${ }^{15}$, article 12 of the convention stipulates that provisions of this convention shall be applied when the condition of application is met (as mentioned previously) to all persons interested claimants and defendants and regardless of their nationalities in civil liability action on the basis of on damageable act ${ }^{16}$.

However, under the second reservation that the second paragraph of article 12 above, it is not allowed to use the provisions of Brussels Collision Convention when all persons interested belonging to the same country that the action is raised before its court, as the national law of this country is the applicable law, despite the fact that the colliding vessels flying a flag of a country member in the convention. It can be observed from the provisions of the Brussels Collision Convention and the first article of it that it is enough to apply its provisions to all persons interested, whether collision occurred on the high seas, territorial waters or internal waters that subject to country approved the convention or to a country does not approve it, that vessels colliding should be belonging to countries approved the convention ${ }^{17}$.

It should be noted that the Brussels Collision Convention has expanded the concept of the collision exceeding the material concept of it, as it is considered as the collision any damage that can be caused to the vessel as a result of turmoil sea waves due to the passage of another vessel, even if no actual physical collision occurs between them ${ }^{18}$.

It is also worth mentioning that the Brussels Collision Convention decided that its provisions do not apply to obligations arising from a contract of carriage or any other contracts ${ }^{19}$. The provisions of this convention also do not apply on collision between two vessels that are linked by a previous contractual relationship, because liability resulting from collision, in this case, is contractual liability subject to the law governs the contract,

\footnotetext{
${ }^{10}$ ibid

11 ibid

12 ibid, p. 72

${ }^{13}$ Sadeq, Hisham Sadiq Ali, and Al Haddad, Hafida Al Syed, "Lessons in the International Private Law, Second Book, Conflict of Laws", 1998-1999, the University of Alexandria, No publisher, p. 423.

${ }^{14}$ Otair, Abdulkadir Hussein, "The Mediator to Explain the Maritime Commercial law ", Library of the Dar Al Thaqafah for Publishing and Distribution, Amman, 1999, p. 416

${ }^{15}$ Bauer (h.), "les traités et les règles de droit international privé matériel", rev.crit.,1966, p.547

${ }^{16}$ Rodiere,"traite général de droit maritime", Dalloz,1972, p.92

${ }_{17}$ Julien le clere," 1,Abordage en droit maritime et en droit fluvial",these,paris,1955,p.10.

${ }^{18}$ Taha, Mustafa Kemal, "Brief in Maritime Law", Alexandria, No Publisher, 1974, Paragraph No. 468

19 Article 10 of the Brussels Collision Convention of 1910
} 
which means that the collision between the towing vessel and ship-trailer is not subject to its provisions ${ }^{20}$.

Collision between a vessel and the vessel used to guidance is also considered as contractual responsibility that comes out of the scope of the provisions of this convention ${ }^{21}$.

The author thinks that the issue of liability of the owner of the vessel regarding the faults of the guide comes out of the scope of application of Brussels Collision Convention if guidance was mandatory where the states of the colliding vessels have not joined the convention of determining the liability of the owner of the vessel ${ }^{22}$.

The issue of liability of the owner of the vessel ${ }^{23}$ also goes out of the scope of application of this convention, and the conflict that can imagine between solidarity liability rules for the physical damage and the special rules to determine the responsibility of vessels ${ }^{24}$. The question of causes for suspension of the process and interruption of pleading of liability action arising from damageable act as a result of the collision ${ }^{25}$, the convention decided in article 7 paragraph 1 that the action of responsibility is time-barred after an interval of two years from the date of the incident, and If the collision was by common fault between two collide vessels and resulting in the death or injury and one of supplier of the two vessels fulfill the compensation for the victim or his heirs, the recourse action brought by this supplier to another supplier demanding him of his share in compensation is time-barred after one year from the date of death ${ }^{26}$.

\section{Jurisprudential Trends on Determining the Applicable Law to the Liability Resulting from Damageable Act on the High Seas}

Jurisprudential trends differ on determining law applicable to responsibility arising from the damageable act on the high seas as a result of collision between vessels belonging to different countries. Some opinions see the need to apply the law of the flag of the vessel causing damage (caused collision) ${ }^{27}$. Some other opinions see the need to apply the law of the flag of the damageable vessel by the collision ${ }^{28}$. This opinion is taken by the International Court of Justice in 1927 in the case of the French vessel (Lotus) which collided with the Turkish vessel (Buzkurt) at sea, the thing which led to severe damage to the Turkish vessel and the lives of its $\mathrm{crew}^{29}$. Third opinion believes of the need to apply what is called public maritime law ${ }^{30}$. While the fourth opinion considers that the law of the court addresses the dispute shall be applied ${ }^{31}$.

As for the validity of the previous trends, the author thinks the following:

1) The trend in which sees the need to apply the law of the flag of the vessel causing collision is based on that the vessel causing collision is the object of the occurrence of the damageable act. Therefore, this basis is assumed that the fault happened above the vessel, which means applying the law of the country that the vessel raises its flag. The matter which the author thinks it is not valid, as the collision is occurred on the high seas which means that the fault did not occur over this vessel, so how can we apply the law of its flag then? ${ }^{32}$ Furthermore, this trend does not cover the hypothesis that the collision is the result of joint fault between colliding vessels.

2) The tendency that sees the need to apply the law of the flag of the damaged vessel as a result of the collision rests on the basis that this vessel is the object of the damageable act. Consequently, such a basis supposes that damage has occurred over this ship, which means to apply the law of its flag as it is the place of the damage. The

\footnotetext{
${ }^{20}$ julien le clere, op.cit.,p.133

${ }^{21}$ Younis, Ali Hassan, "Maritime Law", $1^{\text {st }}$ Edition, Alexandria, 1954, p 427.

${ }^{22}$ Article 5 of the Brussels Collision Convention of 1910

${ }^{23}$ Article 10 of the Brussels Collision Convention of 1910

${ }^{24}$ Sadeq, Hisham Ali, "Conflict of Laws in Delictual Responsibility (Law of Torts) Issues Arising from Maitime Collision and Incidents Occurring on Vessels, ibid, p. 101

${ }^{25}$ Article 7 of the Brussels Collision Convention of 1910 requires in the issue of causes of suspension and interruption of prescription referring to the law of the court that the action is raised.

${ }^{26}$ Article 7/2 of the Brussels Collision Convention of 1910

${ }^{27}$ Daoudi, Ghalib Ali, "International Private Law, First Book in the Conflict of Laws and Conflict of International Jurisdiction and Enforcement of Foreign Awards," Dar Wael for Publication, Amman, 2005, p 229.

${ }^{28}$ Op cit, pp. 229- 230

${ }^{29}$ ibid, pp. 229-230

${ }^{30}$ Sadeq, Hisham Ali, ibid, p. 147

${ }^{31}$ Abdel Aal, Okasha Mohammed, "International Private Law in the United Arab Emirates, Part One: the Conflict of Laws", Dubai Police Academy, 1997, pp. 817.

${ }^{32}$ Bourel(P.),"les conflits de lois en matière d'obligations extracontractuelles", thèse, Rennes- Paris, 1961, p.130
} 
fact which also the author does not recognize its validity, as the collision happens on the high seas, which necessarily means that the damage did not occur over the vessel, but occur to $\mathrm{it}^{33}$. Add to this, this trend assumes wrongly that collision causes damage to only one vessel, so how it will be if the damages of all vessels are equal in collision?

3) The third trend in which sees to apply what is called public maritime law is based on the enforcement of the international norms, which settled on rules for passage to the seas, so it shall be obligatory to refer to them as a standard for measuring the fault of the vessel ${ }^{34}$. Although, these norms are important in detection of the fault that led to the collision, they are not sufficient in itself to determine liability resulting from this collision, they do not show the bases for estimation the compensation, determining the responsibility of the owner of the vessel and they do not address the issue of maritime collision as a result of the common fault ${ }^{35}$.

Despite the fact that the English courts have gone to the possibility of extracting rules governing the former matters through the application of the English maritime law ${ }^{36}$, the idea of public maritime law itself is based on fault illusion, because actually there is no public maritime law, even though the English courts apply maritime law of England as a general maritime law, but such an application is only, in fact, an application of the law of country of the judge $\mathrm{e}^{37}$.

4) The opinion that considers the law of the court addresses the dispute shall be applied to damageable acts that occur on the high seas (many provisions of the courts of different countries adopted this opinion) ${ }^{38}$ is based on practical argument that is the judge knows the content of his law more than any other law, in addition, this opinion is consistent with considerations of justice as at least one of the parties (the claimant) has accepted the application of this law by raising the dispute to the court which would be applied it ${ }^{39}$. However, such a basis is inconsistent with the idea that the judge committed in searching for the content of foreign law similar to the national law in the framework of the international private relations ${ }^{40}$, moreover, it may help the claimant to fraud through raising the action to the court which he/she knows in advance that applying its law gives him/her more care of interests ${ }^{41}$.

In spite of past trends, the author tends to agree with jurisprudence that resolves the issue of maritime collision on the high seas as follows ${ }^{42}$ :

1) If vessels belong to the same country, then the law of common flag between them shall apply, as the law of social center of the international private relationship.

2) If vessels belong to two different countries, the judge shall apply the law of his/her country, as this law is competent alternate one that applies in the assumptions that do not have a rule of conflict.

\section{The Mechanism of Determining the Law Applicable to Damageable Act on the High Seas by the Jordanian Judge}

We had previously pointed out that the Jordanian legislator did not put a rule of conflict to address the issue of determining the law applicable to damageable act on the high seas, and we also had pointed out that Jordan did not approve the Brussels Collision Convention in 1910 related to the maritime collision. This leads us to wonder about the possibility to apply what is predominant in the international private law to solve this dilemma in the light of the text of article 25 of the Jordanian civil code No. 43 of 1976, which stipulates the following: "the principles of the private international law shall be applied in cases where the previous articles do not regulate issues of the conflict of laws".

The author firmly believes that it is not possible to apply the text of article 25 mentioned above in the light of what article 24 of the Jordanian civil code states, "the provisions of the preceding articles shall not apply to if

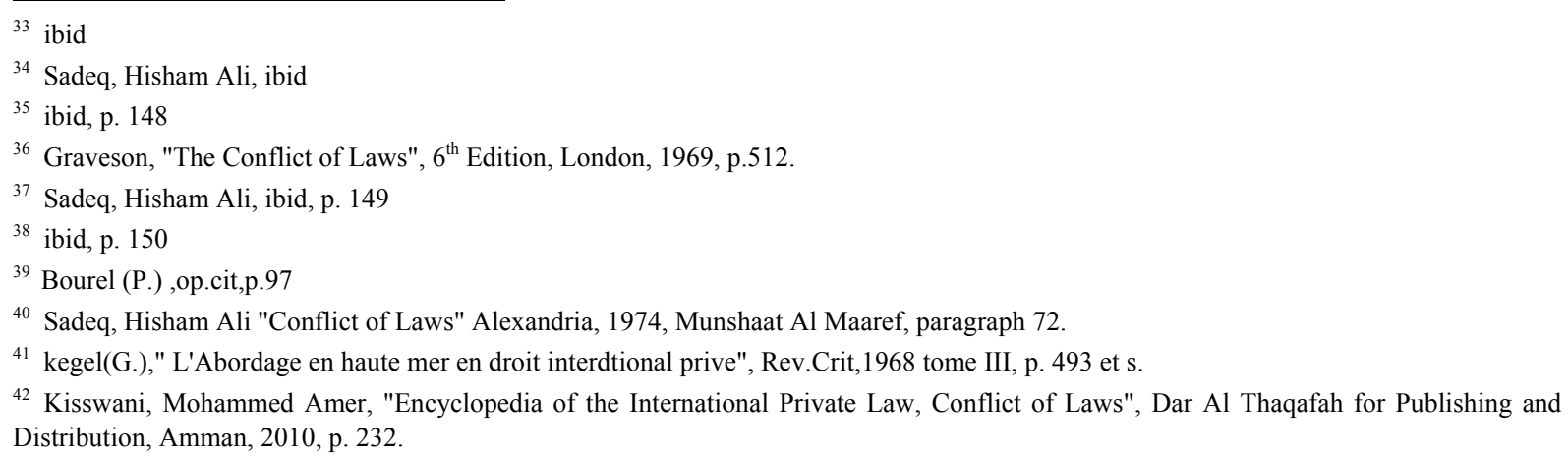


any text in a special law or in valid international convention in the Hashemite Kingdom of Jordan is inconsistent with it".

Thus, the application of the provisions of the Jordanian maritime commercial law No. 12 of $1972^{43}$ as that what the provisions are listed in are special provisions for the provisions of the Jordanian civil code, the author notes that the Jordanian legislator through this law links the legislative jurisdiction in terms of place regarding the maritime collision with the international jurisdiction of Jordanian courts when The action is brought in front of the Jordanian judiciary by the claimant, and a case of jurisdiction of Jordanian courts is available to consider the dispute according to what stated in Articles 27, 28 and 29 of the civil and commercial procedure law No. 24 of $1988^{44}$. Therefore, there is no escape from applying the Jordanian maritime commercial law as it is a direct application law.

Accordingly and based on the provisions of this law, if the collision occurred incidentally, by force majeure or if uncertainty about what causes it, the damaged shall bear the damage inflicted him even if vessels or one of them was anchored at the time of colliding ${ }^{45}$. If the collision is caused by fault of one of the vessels, compensation of the damage is required by the one who is responsible for this collision ${ }^{46}$. If the fault is common, compensation shall be for each vessel according to its fault, but if conditions prevented without proof of this ratio or if the faults seemed equal, shares shall be distributed equally ${ }^{47}$.

According to this law, the damage to vessels, to its cargo, luggage of the sailors, passengers, or any of their money or to any other person found on board of the vessel, the fault vessels carry costs according to its fault and without solidarity towards others ${ }^{48}$. Fault vessel are also obliged solidarity towards third parties to damage arising from the death or injury with keeping the right of the vessel that paid a share exceeds its agreed share to claim, as has been previously explained ${ }^{49}$. If collision occurs by fault of the captain, liability will remain as set above, even if the presence of the captain to the court is mandatory ${ }^{50}$. The preceding provisions also apply in assessing the compensation of damage caused by a vessel to other vessel, to things on board or people as a result of its movement, skipping a movement or not taking care of regulations ${ }^{51}$.

With regard to the action of compensation arising from damage due to the collision, it is time-barred, under this law, after an interval of two years from the date of the incident ${ }^{52}$. However, the claim right of the vessel which

43 Official Gazette, 06/05/1972, No. 2357, pp. 668

${ }^{44}$ Article 27 of the civil and commercial procedure law provides the following:

1) "Regular courts in Hashemite of Jordan practice judiciary on all persons in civil articles, except the articles which may be the right of judiciary delegated to religious courts or special courts under the provisions of any other law.

2) Jordanian courts have jurisdiction to adjudicate in the action even if it is not included in its jurisdiction if the antagonist agrees its jurisdiction explicitly or implicitly.

3) If an action is prosecuted before the Jordanian courts within their jurisdiction, they are also competent to adjudicate in matters related to the original action and to adjudicate each request is associated with this case and requires the proper administration of justice to consider it.

Jordanian courts also have the competence regarding temporary and precautionary procedures implemented in Jordan if they are not competent to address the original case."

Article 28 of the civil and commercial procedure law provides the following:

"Jordanian courts shall have jurisdiction over cases prosecuted against a foreigner who does not have a domicile or place of residence in Jordan as the following circumstances:

1) If he/she has domicile of choice in Jordan.

2) If the action involves property located in Jordan or related to commitment arose, enforced, was obligatory to be enforced in Jordan or related to the declaration of bankrupt.

3) If one of the defendants has domicile or place of residence in Jordan."

Article 29 of the civil and commercial procedure law provides the following:

"If defendant does not attend and the Jordanian courts are not competent to consider the action pursuant to the preceding articles, the court decides by itself that it does not have the jurisdiction."

45 Article 237 of the Jordanian maritime commercial law

${ }^{46}$ Article 238 of the Jordanian maritime commercial law

${ }^{47}$ Article 239 of the Jordanian maritime commercial law

48 ibid

49 ibid

${ }^{50}$ Article 240 of the Jordanian maritime commercial law

${ }^{51}$ Article 241 of the Jordanian maritime commercial law

52 Article 247 of the Jordanian maritime commercial law 
paid share exceeds what is agreed upon is time-barred after one year from the day of payment ${ }^{53}$.

\section{Comparing the Provisions of the Jordanian Maritime Commercial Law with the Provisions of the Brussels Collision Convention of 1910 Concerning Maritime Collision}

Although Jordan did not join the Brussels Collision Convention of 1910 related to maritime collision, we find that the provisions of the Jordanian maritime commercial law match with the provisions of this agreement in terms of the following:

1) If the collision is accidental, due to force majeure or in the event of the emergence of doubt about its causes, we note that article 237 of the Jordanian maritime commercial law corresponds to article 2 of the Brussels Collision Convention. This article provides, if the collision is accidental, if it is caused by force majeure, or if the cause of the collision is left in doubt, the damages are borne by those who have suffered them, even vessels or any one of them may be at anchor at the time of the casualty.

2) If the fault caused by one of the vessels, we note that article 238 of the Jordanian maritime commercial law coincides with article 3 of the Brussels Collision Convention. The article states, if the collision is caused by the fault of one of the vessels, liability to make good the damages attaches to the one which has committed the fault.

3) If the fault is common, we note that article 239 of the Jordanian maritime commercial law agrees with article 4 of the Brussels Collision Convention, the article says, if fault is common between two or more vessels, the liability of each vessel is in proportion to the degree of the faults respectively committed. Provided that if, having regard to the circumstances, it is not possible to establish the degree of the respective faults, or if it appears that the faults are equal, the liability is apportioned equally. The damages caused, either to the vessels or to their cargoes or to the effects or other property of the crews, passengers, or other persons on board, are borne by the vessels in fault in the above proportions without solidarity to third parties. The vessels in fault are obliged towards third parties in respect of damages caused by death or personal injuries however to the right of the vessel which has paid a larger part than that which.

4) Regarding to compensation for damages as a result of the movement of the ship or missing a movement or non-observance of the regulations.

The author notes that article 241 of the Jordanian maritime commercial law corresponds to article 13 of the Brussels Collision Convention, which provides that preceding provisions shall be applied to estimate compensation of damage caused by a vessel to other vessel or persons or things on board of or as a result of execution or non-execution of a manoeuvre or by the non-observance of the regulations, even if no collision had actually taken place.

\section{5) Concerning compensation of damages caused due to a collision.}

The researcher also notes that article 247 of the Jordanian maritime commercial law meets article 7 of the Brussels Collision Convention, to the effect that the compensation action arising from damage due to collision barred after two years from the date of collision. However, the claim right of the vessel which has paid a larger part than that which, have barred after the passage of one year after date of payment.

\section{Conclusion}

The author concludes the following results:

1) Determining the applicable law, in the context of international private relations, related to maritime collision is one of the most accurate and most complex issues that can be faced the national judge when this maritime collision has occurred on the high seas.

2) The impossibility of applying the law of the place where the damageable act is occurred of on the collision that is on the high seas since the meaning of the law of act occurrence is the law of the country in which the act establishes obligation has been happened.

3) The international community interested in the issue of maritime collision that happens on the high seas and in the law applicable to it.3

4) The Brussels Collision Convention in 1910 is a result of the efforts of the international community on the issue of maritime collision on the high seas.

5) Jurisprudential trends differed on the issue of determining the applicable law on liability resulting from damageable act.

${ }^{53}$ ibid 
6) The author agrees with predominant jurisprudence to resolve the issue of maritime collision on the high seas in terms of the need to apply the common law of flag on collided vessels that belong to the same country, and the need to apply the "lex fori", the law of the of the judge's country in the case that vessels belong to different countries.

7) Jordanian legislator does not include within the rules of reattachment of the Jordanian civil code a rule deals and address the issue of the damageable act on the high seas.

8) Jordan does not join and approve the Brussels Collision Convention of 1910 related to the maritime collisions.

9) Although Jordan does not approve the Brussels Collision Convention related to maritime collision, the provisions of the Jordanian maritime commercial law match the Convention.

10) Jordanian legislator Links the international jurisdiction to legislative jurisdiction in terms of the place with respect to damageable act in the high seas, as it is cleared by the Jordanian maritime commercial law that the provisions of the maritime collision contained therein are applied when the action is brought before the Jordanian judiciary and a case of jurisdiction is available according to the Jordanian civil and commercial procedure law.

At the end, the author hopes that the Government of Jordan joins and approves the Brussels Collision Convention of 1910 related to maritime collision through legal means and in conformity with the international community efforts.

\section{References}

Abdel Aal, O. M. (1997). International Private Law in the United Arab Emirates, Part One: the Conflict of Laws. Dubai Police Academy.

Abdullah, I. al-D. (1969). International Private Law, Part Two, in the International Conflict of Laws and International Conflict of Jurisdiction. Dar Al Nahda Al Arabia, Cairo.

Bauer (h.),"les traités et les règles de droit international prive matériel", rev.crit., 1966.

Bourel(P.),"les conflits de lois en matière d'obligations extracontractuelles", thèse, Rennes- Paris, 1961.

Brussels Collision Convention of 1910

Daoudi, G. A. (2001). International Private Law, First Book in the Conflict of Laws and Conflict of International Jurisdiction and Enforcement of Foreign Awards. Dar Wael for Publication, Amman.

Daoudi, G. A. (2005). International Private Law, First Book in the Conflict of Laws and Conflict of International Jurisdiction and Enforcement of Foreign Awards. Dar Wael for Publication, Amman.

Graveson. (1969). The conflict of laws (6th ed). London.

Jordanian Civil and Commercial Procedure Law, No. 24 of 1988

Jordanian Civil Code, No. 43 of 1976

Jordanian Maritime Commercial Law, No. 12 of 1972

Julien le clere,"l'abordage en droit maritime et en droit fluvial", thèse, Paris,1955.

kegel(G.)," L'Abordage en haute mer en droit international privé", Rev.Crit, tome III, 1968.

Kisswani, M. A. (2010). Encyclopedia of the International Private Law, Conflict of Laws. Dar Al Thaqafah for Publishing and Distribution, Amman.

Official Gazette, issue 2357, 6/5/1972

Official Gazette, issue 2645, 1/8/1976

Official Gazette, issue 3545, 2/4/1988

Otair, A. H. (1999). The Mediator to Explain the Maritime Commercial law. Library of the Dar Al Thaqafah for Publishing and Distribution, Amman.

Rodiere,"traite général de droit maritime", Dalloz,1972.

Sadeq, H. A. (1974). Conflict of Laws. Alexandria, Munshaat Al Maaref.

Sadeq, H. A. (2002). Conflict of Laws in Delictual Responsibility (Law of Torts) Issues Arising from Maitime Collision and Incidents Occurring on Vessels. Dar al Fikir Al Jamie, Alexandria. 
Sadeq, H. A. (n.d.). Lessons in Private International Law. Beirut Arab University, University Al Dar Al Jamiea for Printing and Publishing.

Sadeq, H. S. A., \& Al Haddad, H. A. S. (1998-1999). Lessons in the International Private Law, Second Book, Conflict of Laws. The University of Alexandria.

Taha, M. K. (1974). Brief in Maritime Law. Alexandria.

Younis, A. H. (1954). Maritime Law (1st ed.). Alexandria.

\section{Copyrights}

Copyright for this article is retained by the author(s), with first publication rights granted to the journal.

This is an open-access article distributed under the terms and conditions of the Creative Commons Attribution license (http://creativecommons.org/licenses/by/4.0/). 